\title{
PENGEMBANGAN MEDIA PEMBELAJARAN BERBASIS WEBSITE PADA MATERI BANGUN RUANG SISI DATAR DI SMP
}

\author{
Dian Eka Khusnul Khotimah, Slamet Riyadi, Tatik Retno Murniasih \\ Universitas Kanjuruhan \\ dianekakhusnulkhotimah@gmail.com, selametriyadi@unikama.ac.id, tretnom@unikama.ac.id
}

\begin{abstract}
Abstrak: The purpose of this study is to describe the steps of learning media development and design of web-based learning media content with Adobe Dreamweaver CS5 on the building flat side room easy to understand for students as well as test the feasibility of media-based learning website so worthy of use as teaching materials and media self-learning for student. In this research use development method with model used ADDIE model (Analysis, Design, Development, Implementation, Evaluation).Validation trials conducted in this study are validation testing on media experts, validation test on the material experts, as well as trials on students of class VIII B which amounted to 37 students. Based on the results of validation of learning media based on this website, among others, the results of validation testing on media experts with a percentage of $85.83 \%$. Result of validation experiment on material expert with percentage equal to $83.70 \%$. And the results of the test on the students get a percentage of $76.72 \%$. And the average yield percentage of the three test cobatersebut of $82.08 \%$. So from the average result of validation percentage obtained that this web-based learning media declared valid and decent for use in learning.

Kata Kunci: media, website, ADDIE, flat side room
\end{abstract}

Perkembangan ilmu pengetahuan dan teknologi (IPTEK), dewasa ini telah membawa perubahan pesat dalam aspek kehidupan manusia. Salah satu bidang yang mendapatkan dampak cukup berarti dalam perkembangan IPTEK adalah bidang pendidikan, dimana pada dasarnya pendidikan merupakan suatu proses komunikasi dan informasi, media sebagai sarana penyaji ide, gagasan dan materi pendidikan serta siswa. Berkaitan dengan hal tersebut, kemajuan ilmu pengetahuan dan teknologi menuntut seseorang untuk dapat menguasai informasi dan pengetahuan. Dengan demikian, diperlukan suatu kemampuan memperoleh, memilih dan mengolah suatu informasi. Salah satu program pendidikan yang dapat mengembangkan kemampuan tersebut adalah program pendidikan matematika, (Suherman, 2010). Menurut Mardiyono (2012), matematika sebagai ilmu dasar merupakan objek yang bersifat abstrak. Karena matematika memiliki sifat keabstrakan, maka perlu adanya sebuah sarana atau prasarana belajar yang dapat membantu dalam pemahaman materi pelajaran matematika. Pada penelitian pengembangan ini mengangkat materi bangun ruang sisi datar dengan dasar adanya konsep-konsep dalam menemukan suatu rumus dalam bangun ruang sisi datar.

Salah satu cara mengatasi permasalahan tersebut, seseorang guru dapat menggunakan suatu media pembelajaran. Salah satunya dapat menggunakan media pembelajaran berbasis website. Pembelajaran ini lebih dikenal dengan 
e-learning. Pembelajaran berbasis website ini merupakan salah satu sistem pembelajaran yang dapat membantu siswa untuk menambah informasi tentang konsep yang dipelajari melalui kegiatan belajar secara sistematis dengan menggunakan alas bantu berupa komputer, laptop atau yang lainnya serta terhubung dengan jaringan internet. Menurut Koran (2012), media pembelajaran berbasis website adalah pembelajaran yang menggunakan rangkaian elektronik seperti LAN, WAN, atau internet untuk menyampaikan isi pembelajaran yang dapat diakses oleh siapapun, dimanapun, dan kapanpun untuk penggunaanya. Dalam pembuatan media pembelajaran ini menggunakan bantuan software yang bisa membuat website salah satunya adalah Adobe Dreamweaver CS 5.

Berdasarkan latar belakang di atas dapat dirumuskan permasalahannya sebagai berikut: a) Bagaimana mendeskripsikan langkahlangkah pengembangan media pembelajaran dan perancangan konten media pembelajaran berbasis website yang mudah dipahami siswaSMP pada materi bangun ruang sisi datar? dan b) Bagaimana menguji kelayakan media pembelajaran berbasis website dengan Adobe Dreamweaver CS5 pada materi bangun ruang sisi datar untuk kelas VIII di SMP Negeri 4 Singosari sehingga layak digunakan sebagai bahan ajar guru maupun media belajar mandiri bagi siswa?

Asumsi dalam pengembangan ini adalah dengan media pembelajaran berbasis website ini diharapkan siswa akan lebih memahami materi mengenai bangun ruang sisi datar. Dalam mengakses media pembelajaran ini, siswa dapat menggunakan komputer secara pribadi ataupun dapat menggunakan fasilitas sarana prasarana yang ada di sekolah.
Keterbatasan konteks materi pada pengembangan ini adalah materi bangun ruang sisi datar yang meliputi definisi, sifat-sifat, bagian-bagian,jaring-jaring,luas permukaan serta volume dari kubus, balok, prisma, dan limas.

\section{Metode Penelitian}

Pada pengembangan ini, peneliti menggunakan model pengembangan ADDIE. Menurut langkah-langkah perkembangan produk, model pengembangan ini lebih rasional dan lebih lengkap. Model ini dapat digunakan untuk berbagai macam bentuk pengembangan produk seperti model, strategi pembelajaran, metode pembelajaran, media dan bahan ajar. Pengembangan ADDIE adalah model perencanaan pembelajaran yang efektif dan efisien serta prosesnya bersifat interaktif, dimana hasil evaluasi setiap fase dapat membawa pengembangan pembelajaran pembelajaran ke fase sebelumnya. Hasil akhir dari suatu fase merupakan produk awal bagi fase berikutnya. Tahapan dalam model ADDIE yang peneliti gunakan ditunjukkan pada Gambar 1. sebagai berikut:

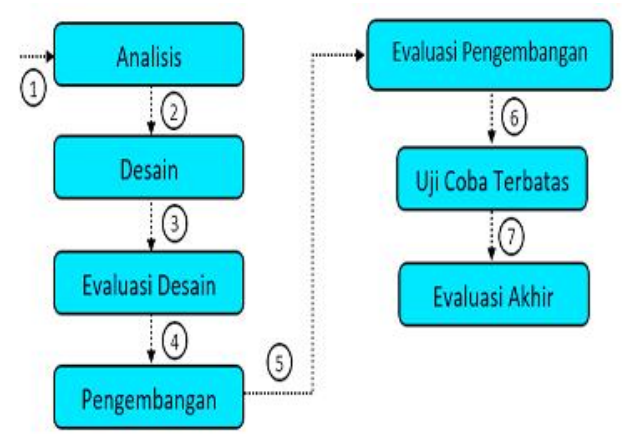

Gambar 1. Model Pengembangan ADDIE Adapun tahapan-tahapan pengembangan dengan model ADDIE dijelaskan sebagai berikut: 
1. Analisis (Analisys), tahap analisis dilakukan untuk menemukan masalah-masalah yang terjadi, pengumpulan informasi terkait dengan fasilitas, infrastruktur, metode pembelajaran yang biasa digunakan guru mengajar, mengumpulkan informasi dari proses kegiatan pembelajaran, dan analisis kebutuhan.

2. Desain (Design), tahap pendesainan ini memiliki kemiripan dengan merancang kegiatan belajar mengajaryaitu menetapkan sebuah tujuan pembelajaran, merancang skenario, merancang perangkat pembelajaran, merancang materi pembelajaran dan alat evaluasi hasil belajar.

\section{Evaluasi Desain (Design} Evaluation), desain yang dibuat oleh peneliti dikonsultasikan kepada ahli materi apakah desain yang telah dibuat ini sudah memenuhi ketepatan, keefektifan, kepraktisan, dan apakah desain materi yang telah disusun sesuai dengan kompetensi dasar dan tujuan pembelajaran.

4. Pengembangan (Development), kerangka konseptual direalisasikan menjadi produk yang siap diujicobakan. Pada tahap pengembangan, perlu mempersiapkan konsep desain, silabus, materi, dan soal-soal uji kompetensi dari kerangka yang dilakukan pada tahap sebelumnya. Selanjutnya dibuat gambar, animasi, atau audio video sehingga akan tercipta produk media pembelajaran.

\section{Evaluasi Pengembangan} (Development Evaluation), merupakan hasil dari tahapan pengembangan untuk dikonsultasikan dan dievaluasi oleh ahli media.

6. Uji Coba Terbatas, selama kegiatan ini menguji produk dengan mengambil 1 kelas VIIIB sebanyak 37 siswa.

7. Evaluasi Akhir (Evaluation), tahap evaluasi akhir dilakukan untuk penyempurnaan media pembelajaran dan mengukur kinerja produk sesuai dengan sasaran dan tujuan awal.

Subjek uji coba dalam pengembangan yaitu ahli media, ahli materi, dan siswa kelas VIII B yang berjumlah 37 siswa di SMP Negeri 4 Singosari. Jenis data yang digunakan menggunakan instrumen berupa angket terstruktur. Adapun aspek-aspek penilaian media yang dipakai dalam instrumen ini diambil dari Walker \& Hess dalam Arsyad (2009) dan Wahono (2006). Dari ketiga sumber tersebut digabungkan dan dimodifikasi sesuai dengan kebutuhan penilaian sesuai Tabel 1.

Tabel 1. Indikator Penilaian

\begin{aligned} & \multicolumn{1}{r}{ No. } \multicolumn{2}{c}{ Aspek } \\ & \hline 1 Ketepatan \\ & \hline 2 Kelengkapan \\ & \hline 3 Kemudahan \\ & \hline 4 Kejelasan \\ & \hline 5 Kesesuaian \\ & \hline 6 Fungsionalitas \\ & \hline 7 Motivasi \\ & \hline 8 Kualitas/tampilan tayangan \\ & \hline 9 Audio \\ & \hline 10 Kualitas dan pengelolaan program \\ & \hline 11 Kompatibilitas \\ & \hline 12 Konsistensi \\ & \hline 13 Keefektivan \\ & \hline 14 Sederhana \\ & \hline 15 Sistematis \\ & \hline\end{aligned}

Untuk menganalisis data angket tanggapan ahli media, ahli materi, dan siswa dapat menggunakan persentase (Akbar dan Sriwiyana, 2011):

(1) Rumus untuk mengolah data item:

1. $\mathrm{V}=\frac{\mathrm{T}}{\mathrm{s}-\mathrm{m}} \times 100 \%$

2. Keterangan:

3. V : validitas

4. TSEV : total skor empirik validator 
5. s-max : skor maksimal yang diharapkan

(2) Rumus untuk mengolah data secara keseluruhan:

6. $\mathrm{V}=\frac{\sum \mathrm{T}}{\sum \mathrm{S}-\mathrm{m}} \times 100 \%$

Keterangan:

$\mathrm{V} \quad$ : validitas

$\sum$ TSEV: jumlah keseluruhan

total skor empirik validator

$\sum \mathrm{S}-$ max: jumlah keseluruhan

skor maksimal yang diharapkan.

Dalam menghitung data setiap item angket, digunakan sistem skor 1, 2, 3, dan 4 . Untuk menginterpretasi hasil ditetapkan kriteria seperti yang ditunjukkan pada Tabel 2.

Tabel 2. Interpretasi Hasil

\begin{tabular}{clll}
\hline \multicolumn{1}{c}{ Kriteria } & \multicolumn{1}{c}{$\begin{array}{c}\text { Tingkat } \\
\text { Kelayakan }\end{array}$} & \multicolumn{1}{c}{ Keterangan } \\
\hline $75,01 \%-100 \%$ & $\begin{array}{l}\text { Sangat } \\
\text { valid }\end{array}$ & $\begin{array}{l}\text { Dapat } \\
\text { tanpa } \\
\text { sedikit }\end{array}$ & $\begin{array}{r}\text { digunakan } \\
\text { revisi/revisi }\end{array}$ \\
\hline $50,01 \%-75 \%$ & $\begin{array}{l}\text { Cukup } \\
\text { valid }\end{array}$ & $\begin{array}{l}\text { Dapat digunakan } \\
\text { dengan revisi kecil }\end{array}$ \\
\hline $25,01 \%-50 \%$ & Tidak valid & $\begin{array}{l}\text { Tidak } \\
\text { digunakan }\end{array}$ & dapat \\
\hline $0 \%-25 \%$ & $\begin{array}{l}\text { Sangat } \\
\text { tidak valid }\end{array}$ & Terlarang digunakan \\
\hline TSumb
\end{tabular}

(Sumber: Akbar dan Sriwiyana, 2011)

\section{Hasil Penelitian dan Pembahasan}

\section{Hasil Pengembangan Produk}

Penelitian pengembangan ini mengacu pada model pengembangan ADDIE. Media pembelajaran berbasis website ini dirancang dengan dua pengguna yaitu pengguna guru dan pengguna siswa. Dimana fungsi pengguna guru juga sebagai administrator. Materi dalam media yang disajikan dengan konsep video dan memiliki fitur kuis yang berbasis komputer. Media pembelajaran berbasis website ini bersifat fleksibel yang dapat digunakan tidak hanya dalam satu materi pokok bahasan. Untuk kuis yang dibuat dapat melihat langsung skor yang diperoleh serta pembetulan jawaban yang benar. Berikut beberapa tampilan media pembelajaran berbasis website.

a. Tampilan awal media (pengguna guru)

Tampilan awal media ini berupa halaman login yang dapat diakses oleh siswa ataupun guru. Apabila login sebagai guru, usernamenya dapat menggunakan NIP/NIK dan untuk passwordnya dapat menggunakan nama belakang.

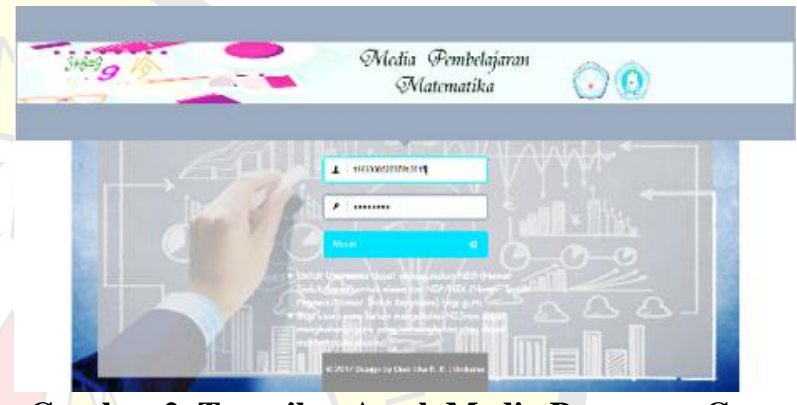

Gambar 2. Tampilan Awal Media Pengguna Guru

b. Tampilan setelah berhasil login (pengguna guru)

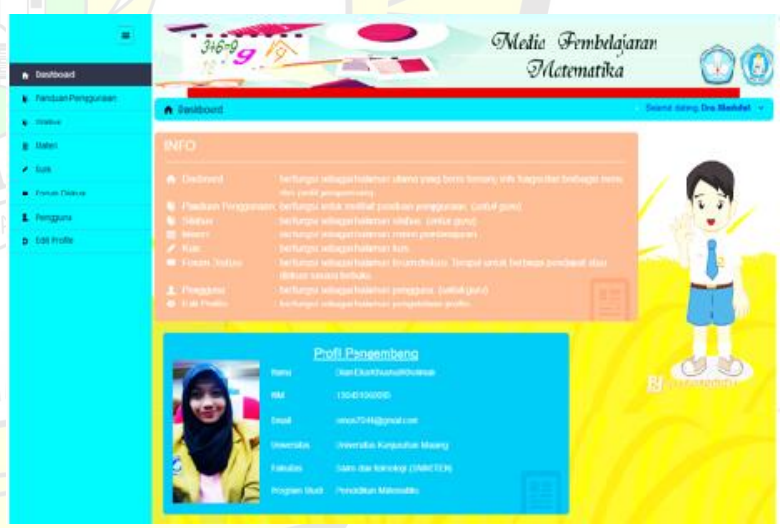

Gambar 3. Tampilan Awal Pengguna Guru Setelah Berhasil Login

c. Tampilan awal media (pengguna siswa)

Tampilan awal media ini sama halnya dengan tampilan awal media pengguna guru. Halaman ini berisikan halaman login. Username pada siswa menggunakan NIS (Nomor Induk Siswa) dan passwordnya adalah siswa1. 


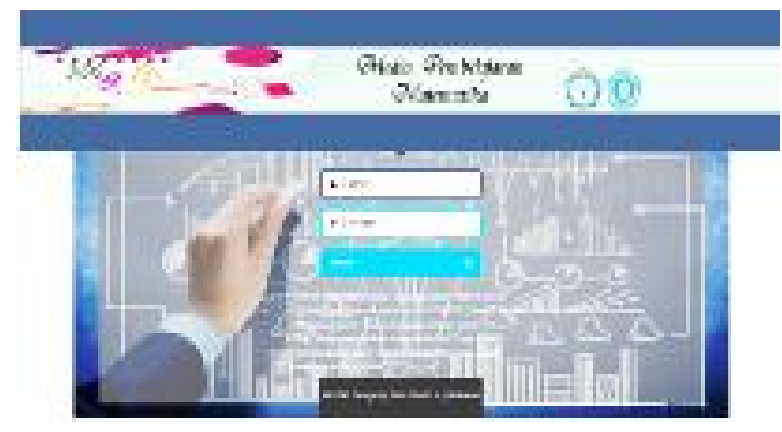

Gambar 4.Tampilan Awal Media Pengguna Siswa

d. Tampilan setelah berhasil login (pengguna siswa)

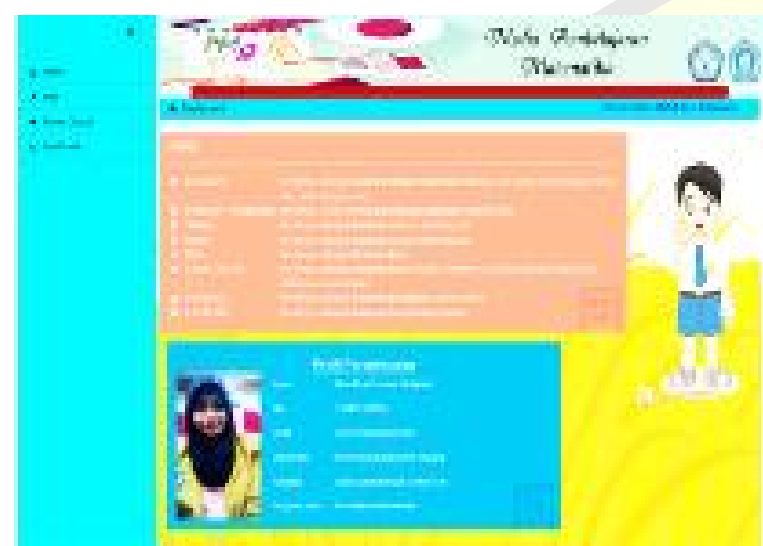

Gambar 5. Tampilan Awal Pengguna SiswaSetelah Berhasil Login

\section{Hasil Validasi}

Setelah dilakukan uji coba secara keseluruhan, maka uji kelayakan media pembelajaran berbasis website ini mendapatkan persentase $85,83 \%$ dari ahli media, persentase $83,70 \%$ dari ahli materi, dan $76,72 \%$ dari siswa. Sehingga didapat persentase rata-rata untuk media pembelajaran berbasis website ini adalah sebesar 82,08\%.Berdasarkan Tabel 2, maka media pembelajaran berbasis website ini valid dan layak digunakan dalam pembelajaran namun dengan sedikit revisi.

\section{Persentase Uji Coba Media Keseluruhan}

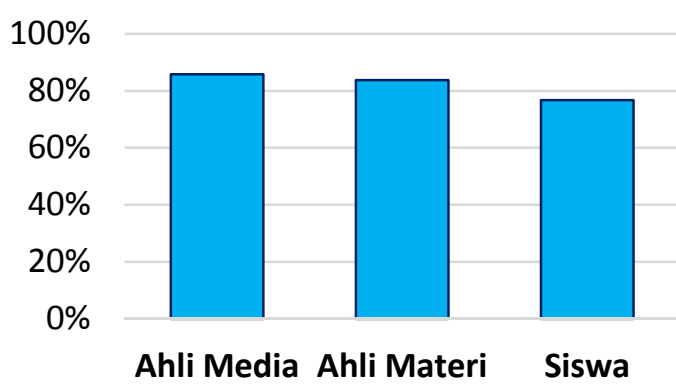

Gambar 6. Persentase Uji Coba Media Keseluruhan

\section{Revisi produk}

Berdasarkan saran dan kritikan dari validator dan responden, revisi media yang dilakukan pengembang adalah membuat desain header menjadi lebih jelas, menambahkan pedoman penggunaan bagi guru dalam bentuk file, serta kualitas audio dalam video pembelajaran perlu diperjelas.

Hasil revisi media yang dilakukan pengembang disajikan sebagai berikut:

a. Desain headersebelum revisi dapat dilihat pada Gambar 7. dan desain header setelah revisi dapat dilihat pada Gambar 8 .

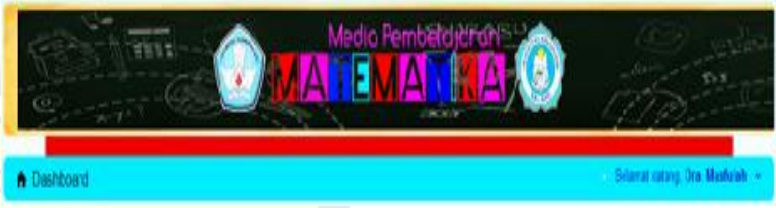

Gambar 7. Tampilan Desain Header sebelum Revisi

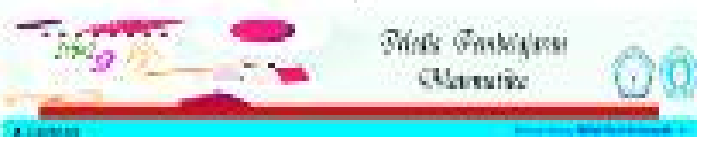

Gambar 8. Tampilan Desain Header setelah Revisi b. Panduan penggunaan (bagi guru)

Panduan penggunaan berfungsi membantu guru dalam mengelola media pembelajaran berbasis website ini. Dari segi 
mengelola silabus, materi, kuis hingga pengguna.

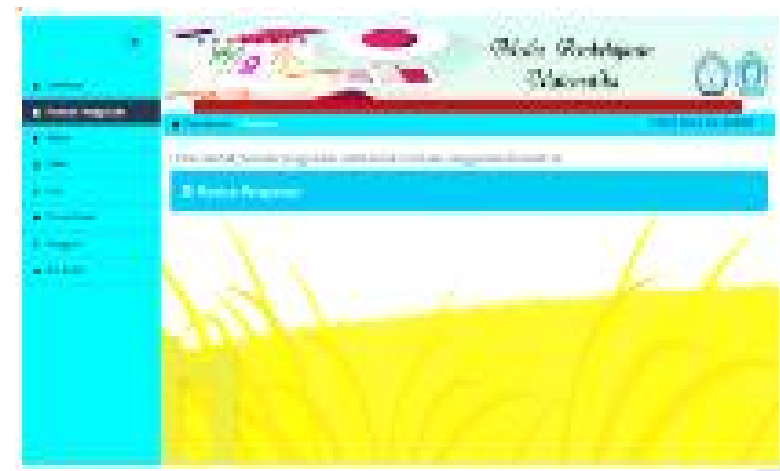

Gambar 9.Tampilan Panduan Penggunaan

Tampilan panduan penggunaan dapat dilihat pada Gambar 9. dan Gambar 10.

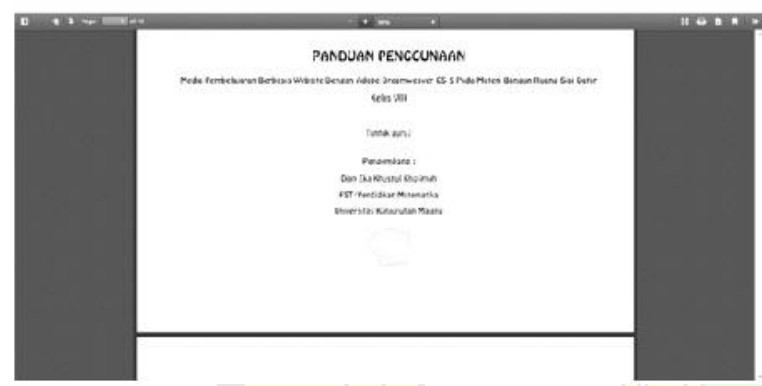

Gambar 10. Tampilan Panduan Penggunaan Dalam Bentuk Pdf

\section{Pembahasan}

Penelitian ini merupakan jenis penelitian pengembangan. Hasil penelitian pengembangan adalah produk media pembelajaran berbasis website dengan Adobe Dreamweaver CS5 pada materi bangun ruang sisi datar kelas VIII.

Penelitian pengembangan dilakukan dengan mengacu pada tahapan penelitian pengembangan model ADDIE. Menurut Pribadi (2009), menjelaskan bahwa model ini memiliki lima fase, yaitu Analysis, Design, Development, Implementation, dan Evaluation. Namun dalam penelitian ini tahapan yang digunakan adalahAnalysis, Design, Development, uji coba terbatas, dan Evaluation.

\section{Simpulan}

Berdasarkan paparan di atas dapat ditarik kesimpulan sebagai berikut:

1. Langkah-langkah pengembangan media pembelajaran berbasis website ini mengacu pada model pengembangan ADDIE. Tahapan terdiri dari: a)Analysis(Analisis), guna mencari informasi permasalahan-permasalahan yang terjadi pada sekolah SMP Negeri 4 Singosari, b)Design (Desain), mulai merancang media yang nanti akan dikembangkan, c) Development (Pengembangan), mulai mengembangkan atau mulai membuat produk, d)Uji Coba pada ahli media, ahli materi, dan siswa kelas VIII B yang berjumlah 37 siswa dan e) Evaluation (Evaluasi Akhir) bertujuan untuk mengevaluasi secara keseluruhan hasil pengembangan produk yang dikembangkan.

2. Kelayakan media pembelajaran berbasis website ini sudah dinyatakan layak dan valid. Hasil validasi yang diperoleh dari beberapa validator yaitu ahli media mendapatkan persentase sebesar 85,83\%, dari ahli materi mendapatkan persentase sebesar 83,70\%, dan dari siswa mendapatkan persentase sebesar 76,72\%. Sehingga didapat prosentase rata-rata sebesar $82,08 \%$ atau memenuhi kriteria valid, sehingga produk yang dikembangkan dapat dipergunakan dengan sedikit revisi.

\section{Daftar Pustaka}

Akbar \& Sriwiyana. 2011. Instrumen Perangkat Pembelajaran. Jakarta: Rosda Karya. 
Arsyad, A. 2009. Media Pembelajaran, edisi

1. Jakarta: PT. Raja Grafindo Persada.

Koran, Jaya Kumar C. 2012. Pengertian elearning.

(Online)

(http://www.edukasi.web.id/2012/11/p

engertian-e-learning.html/, diakses pada tanggal 22 September 2016)

Mardiyono, Sugeng. 2012. Inovasi Pembelajaran Matematika dan Sistem Evaluasinya Berdasarkan Kurikulum Berbasis Kompetensi. (Online) (http://eprints.uny.ac.id/, diakses pada tanggal 15 November 2016)

Pribadi, Benny A. 2009. Model Desain Sistem Pembelajaran. Jakarta: PT. Dian Rakyat.

Suherman, Erman, dkk. 2010. Strategi Pembelajaran Matematika Kontemporer. Bandung: JICA.

Wahono, Romi Satria. 2006. Aspek dan Kriteria Penilaian Media Pembelajaran. (Online) (http://romisatriawahono.net/, diakses pada tanggal 20 Mei 2016) 